\title{
PRODUCTIVITY CHANGE OF MICROFINANCE INSTITUTIONS IN BOSNIA AND HERZEGOVINA
}

Velid Efendić, Nejra Hadžiahmetović

\section{ABSTRACT}

The main aim of this paper is to investigate the productivity changes of microfinance institutions (MFIs) in Bosnia and Herzegovina (BiH) during and after the recent financial crisis. The study covers the period starting from 2008 until 2015. Using the Malmquist Productivity Index (MPI) over the sample of $10 \mathrm{MFI}$ and a balanced panel dataset of 80 observations, this study explores technical and technological change as well as total factor productivity (TFP) change. The empirical findings indicate a decline in TFP in most of the analyzed periods with an average decrease of $2.5 \%$. The study reveals an average technological decline in the industry of $1.7 \%$, while technical efficiency change is recorded at the level of -0.8\%. Overall, crisis efficiency recovery occurred during the period between 2009 and 2013. However, due to technological inefficiencies, average total factor productivity change remains negative. Hence, policy makers need to enhance the technological progress in order to meet their strategic objectives in BiH MFIs.

Keywords: Productivity change, Microfinance institutions, Malmquist productivity index, Bosnia and Herzegovina

JEL classification: $D 24, G 21$

\section{INTRODUCTION}

Since their inception during the 1980s until now, microfinance institutions (MFIs) in $\mathrm{BiH}$ passed through a number of changes. From being driven by their social mission of reaching poor people and alleviating poverty, MFIs shifted their focus on only achieving financial goals (Bassem 2014). However, even though the primary aim of MFIs is to enable access to funds for low-income populations, this goal cannot be achieved without sustainable profitability (Efendic and Hadziahmetovic 2017). The environment in which MFIs operate are significantly influenced by rapid innovations in technology together with the implementation of different policy instruments (Wijesiri and Meoli 2015). These rapid changes resulted in growing competition among MFIs which further on resulted in pushing the production possibility frontier outward and an increase in both outreach and the sustainability of MFIs (Manos and Yaron 2009). Therefore, it is essential for MFIs to operate in an efficient way and in

Velid Efendić, PhD

Associate Professor

University of Sarajevo,

School of Economics and Business

E-mail:velid.efendic@efsa.unsa.ba

Nejra Hadžiahmetović, MA

Research Analyst on World Bank Project

WBG Office in Sarajevo, Bosnia and Herzegovina

E-mail: nhadziahmetovic@worldbank.org 
this framework efficiency and productivity analysis has become quite appealing in its effort to improve outreach, competitiveness and financial sustainability (Bassem 2014).

While there has been a significant amount of research conducted in the analysis of MFIs efficiency, among others: Flückiger and Vassiliev (2007) who investigated two-dimensional efficiency of MFIs in Peru; Gutiérrez-Nieto et al. (2007), Bassem (2008) and Hassan and Sanchez (2009) who analyzed efficiency levels of MFls located in Latin America, the Mediterranean and developing countries respectively. Further on similar research was conducted by Gutiérrez-Nieto et al. (2009) where social and financial efficiency of Asian MFIs was analyzed, Sedzro and Keita (2009) whose study focuses on the efficiency of MFIs located in seven countries from the West African Economic and Monetary Union, Haq et al. (2010) who examined cost efficiencies of MFIs across Africa, Asia and Latin America. Kipesha (2012) conducted a study which focused on South African MFIs and their efficiency while Tahir (2013) assessed the efficiency of MFIs in ASEAN countries; Widiarto and Emrouznejad (2015) went a step ahead and compared two-dimensional efficiency between Islamic and conventional MFIs; Wijesiri and Meoli (2015) analyzed MFIs efficiency in Sri Lanka and Efendic and Hadziahmetovic (2017) who investigated the financial and social efficiency of MFIs in BiH. However, just a few studies have been performed to study the productivity change of MFIs. One of the possible reasons for this is the greater difficulty in finding time series data for MFIs (Wijesiri and Meoli 2015).

The main aim of this study is to explore the productivity change of MFIs in the post-crisis period, or from 2008 and 2009 (the crisis years) until 2015, as a last year of available data for our sample. Although MFIs showed efficiency growth in the after - crisis period in both the social and financial dimension (Efendic and Hadziahmetovic 2017), this study shed light on productivity changes in the specific period of their development. The aim of this study is also to quantify the Malmquist productivity index (MPI) and its components for MFIs that are operating in $\mathrm{BiH}$ over the 7-year period from 2008 to 2015. The microfinance sector in $\mathrm{BiH}$ started to develop as a support to the country recovery from the consequences of war (Bateman et al. 2012) and hence $\mathrm{BiH}$ serves as a good case for this kind of research (Efendic and Hadziahmetovic 2017). In addition to this, the study will help policymakers, as well as industry practitioners and donors to understand the performance and productivity change of MFIs and direct them to construct proper policies, managerial decisions and strategies to enhance the development of MFIs in this region. They should understand the importance of the innovations in MFI and how important is rational use of the resources and service quality to degree of their financial performance. In addition to this, the results of this study will suggest to what extent the technology is relevant for the productivity increase in MFI sector.

The paper is organized as follows. Section 2 of the paper provides a literature review on MFIs productivity changes and Malmquist index as a used methodology in the estimation of productivity changes. Section 3 covers the Malmquist index as a method of the estimation of productivity change and its application in the MFI sector as well as a data collection and statistics as a most significant limitation in efficiency analysis in the MFI sector (Widiarto and Emrouznejad 2015). Section 4 provides the results and the discussion of the results with recommendations. The paper ends with conclusion remarks.

\section{LITERATURE ON MFIS PRODUCTIVITY CHANGES}

In the past two decades, there has been a significant increase in interest for microfinance. Links between the microfinance sector and both national and international economies are becoming stronger (Littlefield and Kneiding 2009; Di Bella 2011) and microfinance is becoming more similar to traditional finance (Wagner and Winker 2012). Lately, the main areas of research interest are efficiency and productivity evaluations of MFIs. Productivity is considered as one of the main engines of a firm's growth and its importance for MFIs is stressed out in numerous studies (Gebremichael and Rani 2012; Bassem 2014; Azad et al. 2015; Mia and Chandran 2015; Wijesiri and Meoli 2015; Tahir and Tahrim 2015; Mia and Bassem 2016; Kar and Rahman 2018; Mia et al. 2018; Ambarkhane et al. 2018).

Efficiency or productivity can be measured using parametric or non-parametric techniques depending on the context of the researcher's study (Mia and Bassem 2016) and it is considered as one of the main challenges of micro-economic analysis (Efendic 2014). The assessment of productivity and its determinants is important and it can significantly improve the utilization of a firm's scarce resources (Isik and Hassan 2003). However, empirical studies on productivity and movements of MFIs are still in their infancy (Wijesiri and Meoli 2015). One of the first attempts to measure efficiency and productivity of global MFIs considering the effect of subsidies was research done by Nawaz (2010). The author conducted a three-stage analysis 
consisted of a calculation of technical and pure efficiency scores, a calculation of Malmquist indices to analyze productivity change and an analysis of Tobit regression. Tahir and Tahrim (2015) conducted a similar study and investigated the efficiency and the productivity of Cambodian microfinance institutions for the period 2008-2011. Results show that both an increase and decline in productivity were attributed to technological change. In addition, the results show that the dominant source of efficiency was scale related meaning that MFIs are operating at an adequate scale of operations but on the other hand they are inefficient when it comes to asset and operating cost management. Bassem (2014) examines productivity changes based on a sample of 33 MFls operating in the Middle East and North African region during the period 20062011. The methodology used is Malmquist productivity index. Research shows that overall productivity declines over the analyzed time period. The author stresses that weakness of the DEA based Malmquist approach should be considered given that this methodology (due to sampling variation) does not consider the uncertainty that surrounds the MPI estimates and MPI components. Wijesiri and Meoli (2015) analyzed a sample of 20 Kenyan MFIs. The analysis is done over the period 2009-2012 and they applied DEA based the Malmquist bootstrap method proposed by Simar and Wilson (1999). In addition, they decompose MPI into changes in technical and technological efficiency to determine the sources of movements in productivity. Further on, the authors decompose technical efficiency on pure and scale efficiency. Empirical results revel that productivity of the majority of MFIs increases over time mainly due to different policy reforms and the application of innovative products that caused positive shift in the production frontier. A major contribution of this study is the use of the bootstrap MPI methodology in order to obtain confidence intervals that will show whether the results indicate real change or are an artifact or sampling noise.

More recently, Mia and Bassem (2016) investigated the productivity of 50 South Asian MFIs for the period 2007-2011. The authors employed the Malmquist productivity index. The results of the study showed that on average productivity grew annually by $2.1 \%$ mainly as a result of the technical efficiency changes which describe the degree to which DMU improves or deteriorates in terms of the efficiency levels. On the other hand, technological change defined as a process by which an optimal combination of inputs and outputs is achieved through better technological and capital equipment used (Chandran and Pandiyan 2008) remain stagnant. This implies that even though microfinance is an innovative approach to financing in itself, flexibility is not the characteristic of the MFI sector. MFIs lack the adoption of innovative financial products and experience in cost cutting delivery methods that can improve their level of productivity (Mia and Bassem 2016). Similarly, analysis on evaluation of productivity of Chinese MFIs done by Mia et al. (2018) implied that MFIs should be encouraged to participate in innovation activities so that improvements in technological change will ultimately lead to improvements of the overall productivity of Chinese MFIs. One of the recent studies is also analysis done by Kar and Rahman (2018) which investigated changes in Total Factor Productivity (TFP) and efficiency of MFIs in developing world. Authors used panel data of $324 \mathrm{MFIs}$ and cover the period of eleven years (2003-2013). Results showed that in overall total factor productivity declined over analyzed period of time. This decline was caused by decrease in scale efficiency, residual scaleefficiency and decrease of residual mix efficiency changes. These imply that MFIs should work on finding ways to improve technical, scale and mix efficiency components through optimal reallocation of available resources (Kar and Rahman 2018). Similar conclusions are developed by Ambarkhane et al. (2018) in their research on measuring TFP change of MFIs in India. They have used Malmquist productivity index to examine 21 major Indian MFIs through the period from 2014 to 2016. Results of their study showed that even though large MFIs are able to catch up with industry best practices there is still a lot of space for improvements especially when speaking about scale efficiency (Ambarkhane et al. 2018).

However, microfinance sector of Bosnia and Herzegovina remain unexplored and not included in any of the previous studies of TFP progress. In addition to this MFIs from $\mathrm{BiH}$ are considered among the most successful on an international scale (Mix and AMFI 2009) which makes BiH a good example efficiency analysis of MFIs (Efendić and Hadžiahmetović 2017). In addition to this, the effect of the crisis on the productivity progress is still unexplored.

\section{Methodology and data}

\subsection{The Malmquist Index}

Efficiency is usually assessed using parametric or nonparametric methods. Data envelopment analysis (DEA) is a non-parametric method that shows an exponential growth in its application in academic research over the last 40 years (Emrouznejad and Yang 2017). DEA is an approach used for the measurement of the relative efficiency of as set of decision-making units (DMUs) using mathematical programming (Wang and Lan 
2011). DEA, in comparison to parametric methods, is based on a complex multi-input/output structure (Cooper et al. 2006). Since the first DEA model was developed - CCR model of Charnes et al. (1978) number of different DEA models have been developed (Wang and Lan 2011) and consequently a large number of DEA applications were reported. Around 10,300 DEArelated research articles have been published in different journals (Emrouznejad and Yang 2017).

Productivity measurement represents one of the important research topics of DEA (Wang and Lan 2011). One of the commonly used approaches for productivity measurement is the DEA based Malmquist productivity index (MPI). Beside this one, there are Fisher index and Tornqvist index (Bassem 2014). However, in comparison to these two MPI has three main advantages (Grifell-Tatje and Lovell 1996): there is no requirement for profit maximization nor for cost minimization assumptions, it does not require information that is related to the prices of inputs and outputs and what is useful for researchers' productivity changes could be further on decomposed into technical efficiency change and technical change. MPI was introduced by Caves et al. (1982) using input and output distance functions. It is further extended by Fare et al. (1992). To define the Malmquist index Fare et al. (1994) defined distance functions with respect to two different time periods; $t$ (based period) and $t+1$ :

$D_{0}^{t}\left(X^{t+1}, Y^{t+1}\right)=\inf \left\{\theta:\left(X^{t+1}, Y^{t+1} / \theta\right) \in S^{t}\right\}$

$D_{0}^{t+1}\left(X^{t}, Y^{t}\right)=\inf \left\{\theta:\left(X^{t}, Y^{t} / \theta\right) \in S^{t+1}\right\}$

In (1) the distance function measures the maximal proportional change in output required to make $\left(X^{t+1}, Y^{t+1}\right)$ which is feasible in relation to the technology at time $\tau$. Similarly, in (2) the distance function measures the maximal proportional change in output required to make $\left(X^{t}, Y^{t}\right)$ which is feasible in relation to technology at time $\mathrm{t}+1$.

Following Fare et al. (1994), $M I_{0}$ for each MFI between $t$ and $t+1$ is defined as the geometric mean of two MPI:

$M I_{0}^{t, t+1}=\left[\frac{D_{0}^{t}\left(X^{t+1}, Y^{t+1}\right)}{D_{0}^{t}\left(X^{t}, Y^{t}\right)} x \frac{D_{0}^{t+1}\left(X^{t+1}, Y^{t+1}\right)}{D_{0}^{t+1}\left(X^{t}, Y^{t}\right)}\right]^{1 / 2}$

The components that are inside the brackets represent the output-based Malmquist productivity indices. They are defined by Caves et al. (1982). The first component inside the brackets is being measured with respect to period t technology while the second component is measured with respect to the $t+1$ technology. If the value of $M I_{0}$ is greater than 1 it indicates productivity progress and vice versa, if $M I_{0}$ is less than 1 it indicates a decline in productivity. In the case when the index is equal to 0 it denotes that there was no change in productivity between periods $t$ and $t+1$. This equation is further decomposed in order to show changes in technical efficiency and changes in frontier technology (Fare et al., 1994). It can be presented as follows:

$M I_{0}^{t, t+1}=\left[\frac{D_{0}^{t}\left(X^{t+1}, Y^{t+1}\right)}{D_{0}^{t}\left(X^{t}, Y^{t}\right)} x \frac{D_{0}^{t+1}\left(X^{t+1}, Y^{t+1}\right)}{D_{0}^{t+1}\left(X^{t}, Y^{t}\right)}\right]^{1 / 2}$

The efficiency change between period $t$ and $t+1$ is measured by the ratio outside the brackets, while geometric mean inside the brackets measures the shift in the production frontier between two-time period $t$ and $t+1$. Further on efficiency change presented in equation (4) can be decomposed into pure and scale efficiency, where pure technical efficiency refers to the MFIs ability to avoid waste by producing as much output as input allows, or on the other hand by using as little input as it is being allowed by output production. Scale efficiency provides information on the MFIs ability to work at its optimum:

$$
\begin{aligned}
& M I_{0}^{t, t+1}=\frac{D_{0}^{t+1}\left(X^{t+1}, Y^{t+1}\right)}{D_{0}^{t}\left(X^{t}, Y^{t}\right)} x \\
& x\left[\frac{D_{0}^{t}\left(X^{t+1}, Y^{t+1}\right)}{D_{0}^{t+1}\left(X^{t+1}, Y^{t+1}\right)} \times \frac{D_{0}^{t}\left(X^{t}, Y^{t}\right)}{D_{0}^{t+1}\left(X^{t}, Y^{t}\right)}\right]^{1 / 2} \\
& \text { Pure efficiency change Scale efficiency change }
\end{aligned}
$$

$D_{C R S}$-the output distance function for constant return to scale (CRS)

$D_{V R S}$ - the output distance function for variable return to scale

The MPI represents a measure of total factor productivity growth (TFP). Values greater than one (in all of the previously explained formulas) are an indication of an improvement in productivity, efficiency and technology from $t$ to $t+1$ period, and vice versa, values lower than one indicates a decrease of performance over an observed time period (Bassem 2014).

\subsection{Data and variables}

Due to constraints related to data availability, data used in this study are obtained from several sources: Official reports on the microcredit system published by the Federal Banking Agency and Banking Agency of Republika Srpska, the MIX market database, reports prepared and published by the Association of MFIs in $\mathrm{BiH}$ (AMFI) covering the period from 2008 to 2013 and financial reports prepared by the MFIs and published 
on their official websites. The sample consists of 10 MFIs (80 observations) and the study covers the period from 2008 to 2015. Out of $10 \mathrm{MFIs}, 9$ of them are registered in Federation of $\mathrm{BiH}(\mathrm{FBiH})$ and one is from Republika Srpska (RS). We included all MFls for which we could collect data on a consistent basis for the previously stated time period. All the monetary data are in Bosnian Convertible Mark (BAM). It should be emphasized that input and output selection is a crucial step in the analysis of financial institution (SeranoCinca et al. 2009), however, there is still no clear guideline for researchers on how to choose between various specifications. In addition, unneeded increases in the number of inputs and outputs should be avoided (Ramanathan 2003). After a detailed review of the available literature on DEA applications we decided to develop a model with two inputs and two outputs. As inputs we selected total assets and number of employees and for the outputs, financial revenue and gross loan portfolio. The number of employees and total assets are our labor and capital variables, while the number of employees addresses the level of efficiency in managing human resources, total assets variable reflects the quality of asset management in one MFI. On the output side, gross loan portfolio is one of the main outputs in the production process of MFI while financial revenue is used as one of the proxies for financial sustainability. A link of the mentioned variables with available literature is summarized in Appendix 1.

Table 1. presents descriptive statistics of the input and output variables we used in the analysis of productivity changes. The table includes data on mean, standard deviation, minimum and maximum values of the sample that include $10 \mathrm{MFls}$ and 80 observations and covers the period from 2008 to 2015.

From the estimated results it could be concluded that the variables we use for our analysis significantly vary among the MFIs' sample. The sample consists of large and small MFIs when measured in terms of gross loan portfolio (Groloan) and total assets (Totas) among others. Accordingly, the distribution of the data from smallest to largest observation/unit show to be with significant differences. The largest unit measured by "gross loans portfolio" and "total assets" are 160 times larger than the smallest ones. When it comes to the financial revenue, the range is even higher (around 314 time higher). However, when it comes to the number of employees, the difference is not so extreme like in previous variables. The number of employees range from 8 to 338 between smallest and largest number of employees in one MFI, what means that the difference between smallest and largest MFI in number of employees 330 employees or is 42 times between smallest and largest number. The identified differences suggesting potential difference in the technical and technological efficiencies of the analyzed units. Number of employees should be in focus as an input of special interest for efficiency analysis. Such significant difference in the number of employees distribution and total assets indicates potential differences in the efficiencies of the managing these inputs. Therefore, the additional exploration of the progress in the technical efficiency is made in next section.

\section{PROGRESS IN THE MICROFINANCE SECTOR IN BOSNIA AND HERZEGOVINA}

Microfinance in $\mathrm{BiH}$ started to develop after the war that happened in the nineties, when the microcredit model was proposed as one of the tools for post-conflict recovery and reconstruction (Bateman and Sinkovic 2017). The majority of MFIs operating today started with their activities during 1997 (Berryman and Pytkowska 2014) where initial support was mainly provided by the World Bank through its Local Initiatives Project (LIP) (WB 2005). In the period from the late 1990s when there was almost no microcredit activity, was by 2009 the second country in terms of microcredit penetration (Bateman 2012).

MFIs' supervision in $\mathrm{BiH}$ is at the entity level and based on the latest reports (as of March 2018) published by the Federal Banking Agency and Banking Agency of RS there are 12 MFIs with a license for business operation (11 are non-profit organization and 1 of which is a for-profit organization) in $\mathrm{FBiH}$ and 13

Table 1: Descriptive statistics of variables (inputs and outputs)

\begin{tabular}{|l|l|l|c|c|c|c|c|}
\hline & & Units & N & Minimum & Maximum & $\begin{array}{c}\text { Mean } \\
\text { Standard } \\
\text { Deviation }\end{array}$ \\
\hline \multirow{2}{*}{ Outputs } & Groloan & BAM `000 & 80 & 1402 & 228088 & 57408.06 & 6655.78 \\
\cline { 2 - 8 } & Finrev & BAM `000 & 80 & 134 & 42124 & 12723.04 & 1338.69 \\
\hline \multirow{2}{*}{ Inputs } & Totas & BAM ‘000 & 80 & 1532 & 251173 & 69145.44 & 7835.32 \\
\cline { 2 - 8 } & Noemploy & Numeric & 80 & 8 & 338 & 166.55 & 11.15 \\
\hline
\end{tabular}

Source: Author's computations 
MFIs in RS. Of those 13 MFIs, 9 are for-profit institutions and 4 non-profit organizations (FBA 2018; ABRS 2018).

Overall, when compared to other financial institutions only small numbers of studies are focused on MFIs and their efficiency (Widiarto and Emrouznejad 2015), and when speaking about $\mathrm{BiH}$, there is a serious research gap (Efendic and Hadziahmetovic 2017). To the best of our knowledge there is only one study that covers "two-dimensional" efficiency of MFIs in $\mathrm{BiH}$. Efendic and Hadziahmetovic (2017) investigated MFIs social and financial efficiency through application of Data Envelopment Analysis. The study covered the period starting in 2008 and ending in 2015 and utilized data for $15 \mathrm{MFIs}$. Results of the empirical analysis showed that there is a suboptimal level of both financial and social efficiency, where financial efficiency levels slightly outperformed those of social efficiency. The study also analyzed the influence of the Global Financial Crisis, and the results showed that MFIs recorded a declining trend in efficiency up to 2010. It could be concluded from the facts mentioned above that there is much space for improvement in MFIs utilization of inputs and that due to lack of available literature it would certainly be useful to conduct additional research on this matter.

\section{RESULTS AND DISCUSSION OF THE RESULTS}

Following the approach proposed by Fare et al. (1994) we have calculated output-oriented Malmquist index, where values of the index which are larger than one indicates positive TFP growth and vice versa, MPI lower than one shows a decline of the TFP over the analyzed period. In order to be able to provide the information on the sources of productivity change we decompose it into technological change (TECH) and technical efficiency change $(\mathrm{EFFCH})$, where TFPCH=technological $x$ technical efficiency change. In the case when we have improvement in the technological change it is considered as an improvement in the best-practice frontier, while the technical efficiency change shows the movement of the industry towards the frontier. Further on, there is a possibility to conduct the decomposition of technical efficiency change into scale change (SECH) and pure efficiency change (PECH). The results are presented in Table 2.

Overall, the results showed that the $\mathrm{BiH}$ micro finance industry has averaged $-2.5 \%$ of TFPCH, suggesting a decline in MFls performance in the period from 2008 up to 2015. Results also show that the average annual rate of technical efficiency change is equal to $-0.8 \%$ while the rate of technological change is $-1.7 \%$. This suggest that a decrease in TFPCH is more a result of the decline in MFIs technology, or moving the frontier than from technical efficiency drop. This suggests systematic changes in the MFI sector which are result of the simultaneous changes in the sector or introducing the new technologies and solutions that are available to MFIs.

When we take a look at the decomposition of the technical efficiency change, our results reveal that pure technical change and scale efficiency change are the same. This means that decline in technical efficien$c y$ is on average affected in the same percent by a decline in managerial practice (pure technical efficiency) as well as by a drop in the optimum size of MFIs (scale efficiency). These results suggest that individual MFIs have to put more effort into the management of their

Table 2: Malmquist index summary of annual means

\begin{tabular}{|c|c|c|c|c|c|}
\hline Year & EFFCH & TECH & PECH & SECH & TFPCH \\
\hline $2008-2009$ & 0.922 & 1.017 & 0.951 & 0.969 & 0.938 \\
\hline $2009-2010$ & 1.021 & 0.898 & 0.991 & 1.031 & 0.917 \\
\hline $2010-2011$ & 1.003 & 1.06 & 1.035 & 0.969 & 1.064 \\
\hline $2011-2012$ & 1.058 & 0.916 & 1.023 & 1.034 & 0.969 \\
\hline $2012-2013$ & 1.011 & 0.939 & 1.009 & 0.994 & 0.949 \\
\hline $2013-2014$ & 0.963 & 1.011 & 0.998 & 0.973 \\
\hline $2014-2015$ & 0.971 & 1.054 & 0.996 & 0.996 & 0.975 \\
\hline \multicolumn{1}{|l|}{ Mean } & 0.992 & 0.983 & & \\
\hline $\begin{array}{l}\text { List of abbreviations: EFFCH-technical efficiency change; TECH-technological change; PECH-pure technical change; } \\
\text { SECH-scale effciency change; TFPCH-total factor productivity change }\end{array}$ \\
$\begin{array}{l}\text { EFFCH=PECH } x \text { SECH } \\
\text { TFPCH=TECH } x \text { EFFCH }\end{array}$
\end{tabular}

Source: Author's computations 
Table 3: Malmquist index summary of BiH MFls means

\begin{tabular}{|c|c|c|c|c|c|}
\hline & EFFCH & TECH & PECH & SECH & TFPCH \\
\hline MFI 1 & 0.978 & 0.973 & 1 & 0.978 & 0.951 \\
\hline MFI 2 & 1 & 0.974 & 1 & 1 & 0.974 \\
\hline MFI 3 & 0.991 & 0.977 & 1 & 0.991 & 0.968 \\
\hline MFI 4 & 0.992 & 0.992 & 0.992 & 1 & 0.984 \\
\hline MFI 5 & 1.007 & 0.993 & 1.007 & 1 & 1 \\
\hline MFI 6 & 1.003 & 0.983 & 1.003 & 1 & 0.986 \\
\hline MFI 7 & 1.007 & 0.991 & 1 & 1.007 & 0.997 \\
\hline MFI 8 & 1.002 & 0.983 & 1 & 1.002 & 0.984 \\
\hline MFI 9 & 0.965 & 0.985 & 0.974 & 0.99 & 0.95 \\
\hline MFI 10 & 0.977 & 0.981 & 0.985 & 0.991 & 0.958 \\
\hline Mean & 0.992 & 0.983 & 0.996 & 0.996 & 0.975 \\
\hline
\end{tabular}

Source: Author's computations

inputs and outputs, and to increase their managerial skills and knowledge simultaneously. This could be a long run strategy for some MFIs to build competitive advantages to their counterparts. In addition to this, the size of some MFIs needs to be adjusted to be optimal to their capacities to be able to exhibit economies of scale. Otherwise, they will perform below the average efficiency of the sector.

Results of the changes in Malmquist index given in Figure 1 show that the microfinance industry has an overall productivity decline of $-6.2 \%$, and $-8.3 \%$ in the years 2008-2009 and 2009-2010, respectively. These years are part of the financial crisis period. However, the year 2010-2011 has a positive TFPCH at 5\% suggesting that measures undertaken during the crisis period by MFIs managements resulted in an increase of their productivity. In addition to this, a negative change was recorded in 2011-2012; 2012-2013 and 2013-2014 with a decline of 3.1\%, 5,1\% and 2.6 respectively, which indicates that crisis lag effects in MFIs in BiH occurred, or, crisis exhibit much longer that it was expected and recorded in other studies. Research conducted by Efendic and Hadziahmetovic (2017) also showed that due to the negative effects of the Global Financial crisis efficiency levels reached their lowest values within the period 2008-2011. Finally, the last two years in our study period showed to have a positive change in productivity suggesting that the effects of the crisis are ending. Accordingly, we can conclude that from 2013. after crisis recovery started, and consolidation of the sector take place.

However, considering the individual efficiency change for the MFIs in our sample, the results showed that changes are significantly different among the analyzed MFIs. From Table 2. and Table 3. it could be concluded that the main source of decrease in TFP is attributed to the technological efficiency change as the results showed that none of 10 MFIs from the

Figure 1: Malmquist index summary of annual means

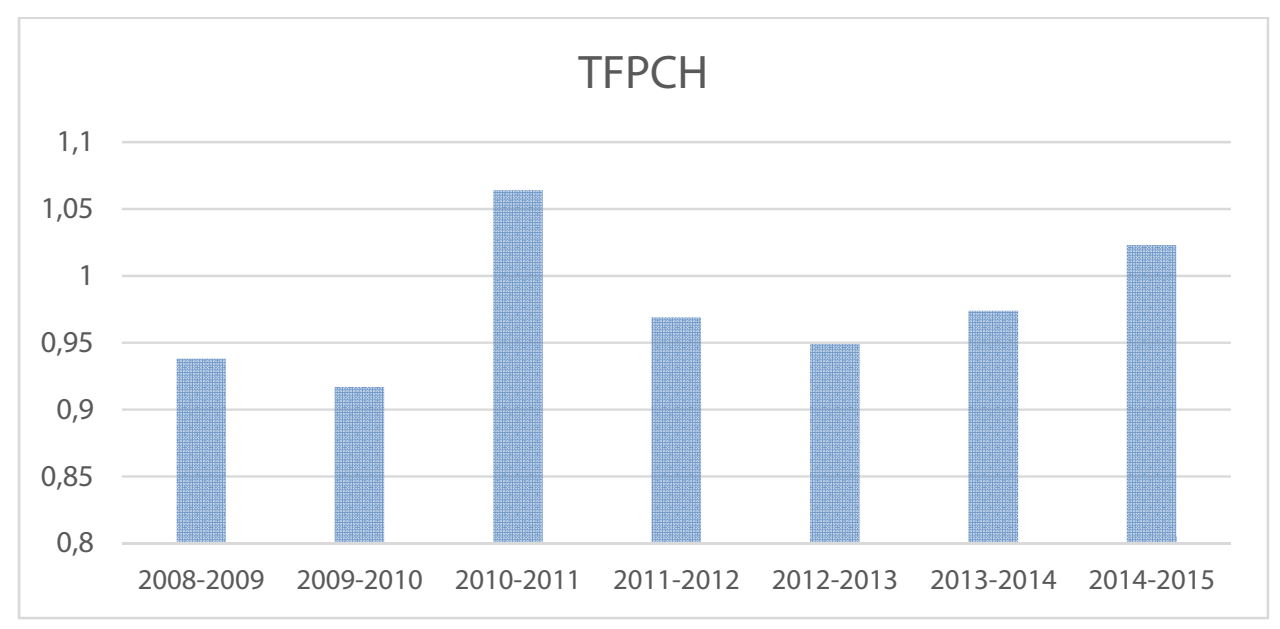

Source: Authors 
sample have shown improvement in "TECH". When analyzing technical efficiency change, 4 out of $10 \mathrm{MFIs}$ have shown improvement in "EFFCH". It is obvious that the main reason for the overall TFPCH decline is attributed to the negative change in TFPCH for 9 out of 10 analyzed MFIs (90\%). Hence, overall technological efficiency changes as well as the technical efficiency change have a negative sign.

As previously mentioned, the decomposition of the Malmquist index allows us to determine the sources of the productivity growth. During the analyzed period our results show that both pure technical efficiency and scale efficiency decreased by $0.5 \%$.

Given results suggest that MFIs experienced a decline in their efficiency during the crisis period. However, TFP increase in the after-crisis period occurred as a result of the better human resource management as well as the increase in the asset quality (Efendic and Hadziahmetovic 2017). In addition to this, it is indicative that increase in the productivity of the employees and more efficient human resources management could be a result of the "cutting costs" strategy. Due to the high dependence of the MFIs as the service sector to the productivity and satisfaction of their employees, the given strategy does not need to lead to good results in the long-run. Therefore, the combination of this strategy with better management of assets resulted in progress in the last three years of the analyzed sample. However, the given results should be considered with special attention. After the given progress and recovery, the new decline is possible as a result of the short run cutting cost strategy.

\subsection{Policy implications and recommendations}

The managers of the MFIs as well as policy makers should put more effort to follow up the changes in the human resources to prevent possible decline produced with the "cutting the costs" strategy. They should understand the importance of the innovations in MFIs and how rational use of the human resources and assets quality lead to the higher financial performance. In addition to this, the results of this study will provide the information to what extent the technology is relevant for the productivity increase in MFI sector. Due to the high relevance of the technology for the productivity improvement, as Chan and Lin (2015) also suggested, MFIs should particularly invest in better use of ICT for more effective monitoring of the old client and new client acquisition, better service delivery and better assets management. Accordingly, MFIs could boost their productivity and reach higher level of the scale efficiency to meet their goals and higher financial performance. Therefore, the introduction the ICT into daily financial operations should boost technological progress in MFIs (Mia et al. 2018), and that should lead to the better clients and loans monitoring system, better service delivery and financial performance (Kar et al. 2018). Finally, using the synergies from MFIs which have highest performance, as Le et al. (2018) also suggested, the policymakers could support the transfer of innovations to other MFIs and on that way increase the productivity of the sector as a whole. Finally, this should lead to the higher asset quality and the productivity growth of MFIs.

\section{CONCLUSION}

Study examined the productivity change in $\mathrm{BiH}$ MFls during the period from 2008 to 2015 by employing the Malmquist productivity index. The sample included $10 \mathrm{MFIs}$ and a balanced panel dataset of 80 observations. After a detailed analysis of the available literature we decided on a combination of input and output variables. For our analysis we specified a combination of two inputs and two outputs: total assets and number of employees as inputs and gross loan portfolio and financial revenue as outputs.

The results of our empirical analysis indicate the following: The empirical findings indicate a decline in TFP in most of the analyzed periods with an average decrease of $2.5 \%$. The study reveals an average technological decline of the industry for $1.7 \%$, while technical efficiency change is recorded at the level of $-0.8 \%$. Even though results showed recovery during the period 2009-2013, due to technological inefficiencies the average TFP change remains negative. Our results reveal that none of the $10 \mathrm{MFIs}$ from the sample have shown an improvement in TECH over the analyzed time period. Hence, policy makers need to enhance technological progress in order to meet their strategic objectives in BiH MFIs. Further, the decomposition of MPI allowed us to investigate sources of productivity change. Accordingly, the results of our analysis showed that during the observed period, $\mathrm{BiH}$ MFIs experienced a decrease of $0.5 \%$ in both pure technical and scale efficiency, so it can be concluded that both bad management practices and work which is not on the optimal scale are sources of the average productivity decline. Results of this analysis strongly support previous analysis conducted by Efendic and Hadziahmetovic (2017) suggesting that MFIs in $\mathrm{BiH}$ have efficiency levels which are quite below optimal level and that MFIs are undoubtedly wasting their resources.

The study also indicated that MFls in $\mathrm{BiH}$ are using 
too much labor (employees) and capital (assets) for the level of their outputs. When speaking about crisis and post-crisis period results, changes in the Malmquist index have shown that the microfinance industry has an overall productivity decline in the study period of $-6.2 \%$ and $-8.3 \%$ in the year $2008-2009$ and 2009-2010 respectively. The years mentioned are part of the financial crisis period. However, in the years 2010-2011 results have shown a positive TFPCH at the level of $5 \%$ suggesting that measures undertaken by MFIs management during the crisis resulted in an increase of their productivity. In addition to this, a negative change was recorded in 2011-2012; 2012-2013 and $2013-2014$ with a decline of 3.1\%, 5,1\% and $2.6 \%$ respectively, which indicates that a crisis lag effect in MFIs in BiH occurred, and that the crisis lasted much longer than was expected. Also, a potential cause of this subsequent decline in productivity could be that MFIs did not apply adequate measures that would lead to sustainable recovery and increase in productivity level but rather focused on short-term results.

\section{REFERENCES}

Ambarkhane, D., Singh, A. S., and Venkataramani, B. 2018. Measuring total factor productivity change of microfinance institutions in India using Malmquist productivity index. Indian Growth and Development Review 12 (1): 105-130.

Azad, M. A., Masum, A. K., Munisamy, S. and Sharmin, D. F. 2015. Efficiency analysis of major microfinance institutions in Bangladesh: A Malmquist index approach. Quality \& Quantity 50 (4): 1525-1537.

Bassem, B. S. 2014. Total factor productivity change of MENA microfinance institutions: A Malmquist productivity index approach. Economic Modelling 39: 182-189.

Bateman, M. and Chang, H. 2012. Microfinance and the Illusion of Development: From Hubris to Nemesis in Thirty Years. World Economic Review 1: 13-36.

Bateman, M. and Sinkovic, D. 2017. Bosnia's post conflict microfinance experiment: A new Balkan tragedy. In Seduced and Betrayed: Exposing the Contemporary Microfinance Phenomenon, 127-146. Albuquerque: University of New Mexico Press.

Bella, G. D. 2011. The Impact of the Global Financial Crisison Microfinance and Policy Implications. IMF Working Papers 11(175).

Caves, D. W., Christensen, L. R. and Diewert, W. E. 1982. The Economic Theory of Index Numbers and the Measurement of Input, Output, and Productivity. Econometrica 50 (6): 1393 - 1414.
Chan, S. H. and Lin, J. J. 2015. Microfinance Products and Service Quality in Financial and Quasi-Financial Institutions in China. Strategic Change 24: 267-284.

Chandran, V. G. and Pandiyan, V. 2008. Technical efficiency and technological change in Malaysian service industries. Applied Economics Letters 15 (8): 655-657.

Cooper, W. W. 2006. Introduction to data envelopment analysis and its uses: with DEA-solver software and references. New York: Springer.

Efendic, V. 2014. Efikasnost banaka u Jugoistocnoj Evropi s posebnim osvrtom na Bosnu i Hercegovinu. Sarajevo: Ekonomski fakultet Sarajevo.

Efendic, V. and Hadziahmetovic, N. 2017. The social and Financial Efficiency of Microfinance Institutions: The Case of Bosnia and Herzegovina. South East European Journal of Economics and Business 12 (2): 85-101.

Efendic, V. and Hadzic, F. 2017. Business Model and Operational Efficiency of Microfinance in Bosnia and Herzegovina: Lessons for Islamic Microfinance. In Critical Issues and Challenges in Islamic Economics and Finance Development, 191-211. London: Palgrave Macmillan.

Emrouznejad, A. and Yang, G. 2017. A survey and analysis of the first 40 years of scholarly literature in DEA: 19782016. Socio-Economic Planning Sciences 61 (1): 1-5.

Färe, R., Grosskopf, S., Norris, M. and Zhang, Z. 1994. Productivity Growth, Technical Progress, and Efficiency Change in Industrialized Countries. The American Economic Review 84 (1): 66-83.

Flückiger, Y. and Vassiliev, A. 2007. Efficiency in Microfinance Institutions:An Application of Data Envelopment Analysis to MFIs in Peru. In: Balkenhol B. (eds) Microfinance and Public Policy, 89-110. London: Palgrave Macmillan.

Gebremichael, B. Z. and Rani, D. L. 2012. Total Factor Productivity Change of Ethiopian Microfinance Institutions (MFIs): a Malmquist Productivity Index Approach (MPI), European Journal of Business and Management 4 (3): 105-114.

Grifell-Tatje, E. and Lovell, C.A.K 1996. Deregulation and Productivity Decline: The Case of Spanish Savings Banks. European Economic Review 40: 1281-1303.

Gutiérrez-Nieto, B., Serrano-Cinca, C. and Molinero, C. M. 2007. Microfinance institutions and efficiency. Omega 35 (2): 131-142.

Hassan, K. M. and Sanchez, B. 2009. Efficiency Analysis of Microfinance Institutions in Developing Countries. SSRN Electronic Journal.

Hermes, N., Lensink, R. and Meesters, A. 2011. Outreach and Efficiency of Microfinance Institutions. World Development 39 (6): 938-948.

Isik, I. and Hassan, M. K. 2003. Financial deregulation and total factor productivity change: An empirical study of Turkish commercial banks. Journal of Banking \& Finance 27 (8): 1455-1485. 
Kablan, S. 2012. Microfinance efficiency in the West African Economic and Monetary Union: have reforms promoted sustainability or outreach? Munich RePEcArhive.

Kar, A. K. and Rahman, S. 2018. Changes in total factor productivity and efficiency of microfinance institutions in the developing world: A non-parametric approach. Economic Analysis and Policy 60: 103-118.

Kipesha, E. 2012. Efficiency of Microfinance Institution in East Africa: DEA. European Journal of Business and Management 4 (17): 77-88.

Le, V., Vu, X-B (Benjamin) and Nghiem, S. 2018. Technical efficiency of small and medium manufacturing firms in Vietnam: A stochastic meta-frontier analysis. Economic Analysis and Policy 59: 84-91.

Lee, B.L. 2013. Productivity Performance of Singapore's Retail Sector: A Two-Stage Non-Parametric Approach. Economic Analysis and Policy 43 (1): 67-77.

Littlefield, E. and Kneiding, C. 2009. The Global Financial Crisis and Its Impact on Microfinance. CGAP 52: 1-7.

Mia, M. A. and Chandran, V. G. 2015. Measuring Financial and Social Outreach Productivity of Microfinance Institutions in Bangladesh. Social Indicators Research 127(2): 505-527.

Mia, M. A. and Soltane, B. I. 2016. Productivity and its determinants in microfinance institutions (MFIs): Evidence from South Asian countries. Economic Analysis and Policy 51: 32-45.

Mia, M. A., Zhang, M., Rasiah, R. and Alam, A. F. 2018. Evaluating Productivity of Chinese Microfinance Institutions: A Malmquist Approach. The Chinese Economy 51(5): 432-445.

Milford, B., Sinkovic, D. and Skare, M. 2012. The contribution of the microfinance model to Bosnia's post-war reconstruction and development: how to destroy and economy and society without really trying. Austrian Foundation for Development Research (Ofse) 36: 4-31.

Nawaz, A. 2010. Efficiency and productivity of microfinance: incorporating the role of subsidies. Working Papers CEB: 10-009.

Ramanathan, R. 2003. An Introduction to data envelopment analysis: A tool for performance measurement, 174-175. New Delhi: SAGE Publications.
Sedzro, K. and Keita, M. 2009. Assessing the Efficiency of Microfinance Institutions Using Data Envelopment Analysis. Journal of International Finance \& Economics 9 (2): 54-67.

Serrano-Cinca, C., Gutiérrez-Nieto, B. and Molinero, C. M. 2009. Social Efficiency in Microfinance Institutions. Journal of The Operational Research Society 60 (19): 104-119.

Simar, L. and Wilson, P. W. 1999. Estimating and bootstrapping Malmquist indices. European Journal of Operational Research 115 (3): 459-471.

Tahir, I. M. and Tahrim, S. N. C. 2013. Efficiency Analysis of Microfinance Institutions in ASEAN: A Proposed Efficiency Framework. Interdisciplinary Journal of Research in Business 3 (4): 13-23.

Tahir, I. and Tahrim, S. 2015. Efficiency and Productivity Analysis of Microfinance Institutions in Cambodia: A DEA Approach. International Review of Business Research Papers 11 (1): 25-42.

Wagner, C. and Winkler, A. (2012). The Financial Crisis - a Microfinance Perspective. Die Unternehmung 66 (4): 324-339.

Walter, I. and Krauss, N. A. 2008. Can Microfinance Reduce Portfolio Volatility? Economic Development and Cultural Change 58 (1): 85-110.

Wang, Y. and Lan, Y. 2011. Measuring Malmquist productivity index: A new approach based on double frontiers data envelopment analysis. Mathematical and Computer Modelling 54 (11-12): 2760-2771.

Widiarto, I. and Emrouznejad, A. 2015. Social and financial efficiency of Islamic microfinance institutions: A Data Envelopment Analysis application. Socio-Economic Planning Sciences 50: 1-17.

Wijesiri, M., Viganò, L. and Meoli, M. 2015. Efficiency of microfinance institutions in Sri Lanka: a two-stage double bootstrap DEA approach. Economic Modelling 47: 74-83.

Wijesiri, M. and Meoli, M. 2015. Productivity change of microfinance institutions in Kenya: A bootstrap Malmquist approach. Journal of Retailing and Consumer Services 25: 115-121.

World Bank Report. 2005. In WB Site resources. http://siteresources.worldbank.org/INTBOSNIAHERZ/Resources/ LIP2.pdf. (accessed August 5, 2018). 


\section{APPENDIX 1: Inputs/Output variables - Link with available literature}

\begin{tabular}{|c|c|c|c|}
\hline Inputs & Definition & Link with Literature & Units \\
\hline $\begin{array}{l}\text { Noemploy } \\
\text {-Employees }\end{array}$ & $\begin{array}{l}\text { The number of individuals who are actively em- } \\
\text { ployed by an MFI. This number includes con- } \\
\text { tract employees or advisors who dedicate the } \\
\text { majority of their time to the MFI }\end{array}$ & $\begin{array}{l}\text { Bassem(2008). Hassan and Sanchez } \\
\text { (2009). Sedzro and Keita (2009). Kipesha } \\
\text { (2012). and Haq et al. (2010).Widiarto and } \\
\text { Emrouznejad (2015).Wijesiri et al. (2015). } \\
\text { Lebovics et al. (2016). Mia and Bassem } \\
\text { (2016). Efendic and Hadziahmetovic } \\
\text { (2017) }\end{array}$ & Numeric \\
\hline $\begin{array}{l}\text { Totass- } \\
\text { Total assets }\end{array}$ & Total of all net asset accounts. & $\begin{array}{l}\text { Bassem (2008). Gutiérrez-Nieto et al. } \\
\text { (2009). Hassan and Sanchez (2009). } \\
\text { Widiarto and Emrouznejad (2015). Wijesiri } \\
\text { et al. (2015). Tahir (2013). Kipesha (2012). } \\
\text { Efendic and Hadziahmetovic (2017) }\end{array}$ & $\begin{array}{l}\text { BAM } \\
' 000\end{array}$ \\
\hline Outputs & Definition & Usage in Literature & Units \\
\hline $\begin{array}{l}\text { Finrev - } \\
\text { Financial } \\
\text { Revenue }\end{array}$ & $\begin{array}{l}\text { Revenue from loan portfolio. It is used as an } \\
\text { output in the production approach and a proxy } \\
\text { for sustainability since an MFI that cannot col- } \\
\text { lect enough revenue will not be viable to oper- } \\
\text { ate in the long run by itself }\end{array}$ & $\begin{array}{l}\text { Gutiérrez-Nieto et al. (2009). } \\
\text { Hassan and Sanchez (2009). Kipesha } \\
\text { (2012). Widiarto and Emrouznejad (2015). } \\
\text { Wijesiri et al. (2015). Lebovics et al. (2016). } \\
\text { Mia and Bassem (2016). Efendic and } \\
\text { Hadziahmetovic (2017) }\end{array}$ & $\begin{array}{l}\text { BAM } \\
' 000\end{array}$ \\
\hline $\begin{array}{l}\text { Groloan - } \\
\text { Gross Loan } \\
\text { Portfolio }\end{array}$ & $\begin{array}{l}\text { The outstanding principal balance of all of an } \\
\text { MFI's outstanding loans, including current, de- } \\
\text { linquent, and restructured loans, but not loans } \\
\text { that have been written off. It does not include } \\
\text { interest receivable }\end{array}$ & $\begin{array}{l}\text { Gutiérrez-Nieto et al. (2007). } \\
\text { Gutiérrez-Nieto et al. (2009). Kipesha } \\
\text { (2012). } \\
\text { Hassan et al. (2012). Widiarto and } \\
\text { Emrouznejad (2015).Lebovics et al. (2016). } \\
\text { Efendic and Hadziahmetovic (2017) }\end{array}$ & $\begin{array}{l}\text { BAM } \\
000\end{array}$ \\
\hline
\end{tabular}

\section{APPENDIX 2: List of MFls included in the sample}

\begin{tabular}{|l|l|}
\hline Name of MFI & Web address \\
\hline EKI Sarajevo & www.eki.ba \\
\hline LIDER Sarajevo & www.lider.ba \\
\hline LOK Sarajevo & www.lok.ba \\
\hline MI-BOSPO Tuzla & www.mi-bospo.org \\
\hline MIKRA Sarajevo & www.mikra.ba \\
\hline MIKRO ALDI Gorazde & www.mikroaldi.org \\
\hline MIKROFIN Banja Luka & www.microfin.com \\
\hline PARTNER Tuzla & www.partner.ba \\
\hline PRVA ISLAMSKA MCF Sarajevo & \\
\hline SUNRISE Sarajevo & www.microsunrise.ba \\
\hline
\end{tabular}

